\title{
Análise retórica e moral de Antígona
}

\section{Rhetorical and Moral Analysis of Antigone}

\author{
Eleonoura Enoque Silva, Martha Solange Perrusi, \\ Antonio Henrique Coutelo de Moraes*
}

\section{RESUMO}

Sófocles escreveu a tragédia Antígona - peça representada pela primeira vez em 441 a.C, em Atenas -, que tem como tema central um problema prático de conduta, envolvendo aspectos morais e políticos. Nessa obra, o tragediógrafo colocou questões fundamentais para discussão e reflexão, principalmente a do limite da autoridade do Estado sobre a consciência individual e o conflito entre a lei não escrita e a lei escrita. Nosso propósito, neste trabalho, será analisar como Aristóteles, em sua obra Retórica, discute o tema e as questões fundamentais de Antígona a partir dos conceitos de lei, justiça e equidade. Continuaremos nossa análise com um pensador contemporâneo, Cornelius Castoriadis, que considera a tragédia um dos mecanismos de instituição da democracia grega, isto é, do exercício político na polis. Com base nas ideias desses autores, pretendemos primeiro discutir o conflito entre as leis à luz da retórica aristotélica e, num segundo momento, discutir bom senso e descomedimento a partir de considerações trazidas por Castoriadis.

Palavras-chave: Antígona; Retórica Aristotélica; Castoriadis.

* Universidade Católica de Pernambuco (UNICAP). 
Silva, E. E.;

Perrusi, M. S.;

Moraes, A. H.

Análise retórica

e moral de

Antígona

Sophocles wrote the tragedy Antigone - a play performed for the first time in 441 b.C. in Athens - which has as its central theme a practical problem of conduct involving moral and political aspects. In this work, the dramatist posed fundamental questions for discussion and reflection, mainly the limit of the authority of the State on the individual conscience and the conflict between unwritten law and written law. Our purpose in this work is to analyze how Aristotle, in his Rhetoric, discusses the theme and fundamental questions of Antigone, from the concepts of law, justice, and equity. We will continue our analysis with a contemporary thinker, Cornelius Castoriadis, who considers tragedy one of the mechanisms of institution of Greek democracy, that is, of the political exercise in the polis. Based on the ideas of these authors, we first intend to discuss the conflict between laws in the light of Aristotelian rhetoric, and, in a second moment,discuss reason and immoderation based on considerations brought by Castoriadis.

Keywords: Antigone; Aristotelian Rhetoric; Castoriadis. 

tema desse trabalho consiste em uma discussão das confluências entre ética, política e retórica na obra Antígona, de Sófocles, com objetivo de analisar alguns conflitos entre os protagonistas a partir de obras de Aristóteles e Castoriadis.

Sabemos que Antígona foi uma das tragédias mais estudadas e interpretadas em diversas áreas do conhecimento, como Filosofia, Direito, História, Ciências Politicas, Psicologia, Letras, Artes Cênicas, dentre outras. Mas o que nos chama atenção para revisitar a obra pelo viés da Filosofia é o fato de haver certos aspectos observados e indicados por filósofos antigos e contemporâneos que ainda não foram suficientemente discutidos e refletidos nem, sobretudo, reunidos em um mesmo trabalho.

Nas seções a seguir, inicialmente, faremos algumas considerações sobre Sófocles e sua obra Antígona, contextualizando-a no âmbito da história e da política da Grécia antiga. Em seguida, apresentaremos um breve resumo dessa obra. Por fim, faremos uma análise retórica dos gêneros do discurso e dos tipos de provas que identificamos nessa tragédia. 
Silva, E. E.; Perrusi, M. S.; Moraes, A. H. Análise retórica e moral de Antígona

Revista Letras, Curitiba, UfPR, n. 97, pp. 38-54, jan./jun. 2018. ISSN 2236-0999 (versão eletrônica)

\section{Aspectos históricos e políticos nas tragédias}

No séc. V a.C., com o surgimento da democracia grega, houve um grande interesse dos tragediógrafos, filósofos e sofistas pelos problemas de ética e política, bem como pela questão do homem enquanto cidadão da polis ${ }^{1}$. Isso porque a democracia representava a possibilidade de se resolverem, através do entendimento mútuo, as divergências e diferenças existentes na sociedade em nome de um interesse comum. As deliberações seriam feitas, então, em reuniões de cidadãos chamadas de assembleias. Isso significa que as decisões seriam tomadas por consenso, o que implicaria persuadir, convencer, justificar, explicar. Assim, surgem as artes do discurso: retórica e oratória. Na medida em que a palavra passa a ser livre, ela se torna o instrumento dos indivíduos para defenderem seus interesses, direitos e propostas (MARCONDES, 1998).

É nesse contexto histórico e político que entendemos o surgimento do discurso filosófico e o sentido das mudanças sociais e culturais, como a tragédia, que se tornou parte de uma cerimônia cívica em que virtudes morais e políticas são exaltadas. Como exemplo, temos Sófocles (496-406 a.C.), cujas tragédias destacam as temáticas das virtudes, dos direitos, da verdade e da justiça, principalmente, nas obras Édipo Rei (430 a.C.) e Antígona (441 a.C.) (MARCONDES, 1998).

A respeito das tragédias, Aristóteles considera que o objetivo delas era provocar uma forte impressão no público para que refletissem sobre as paixões (pathos) e os vícios humanos. Em sua obra Poética (IV-26), assim conceitua a tragédia:

Tragédia é a representação de uma ação elevada, de alguma extensão e completa, em linguagem adornada, distribuídos os adornos por todas as partes, com atores atuando e não narrando; e que, despertando piedade e temor, tem por resultado a catarse dessas emoções (ARISTÓTELES, 1973).

A catarse, para Aristóteles, seria um elemento chave na compreensão da tragédia, entendida como purificação das emoções de "terror e piedade". A bem dizer, a questão interessante do processo catártico de uma encenação trágica é a mobilização por conta de um erro do personagem trágico que carrega em si todo o peso da comunidade. É por isso que se pode dizer que a audiência purifica as emoções. Como diz Rachel Gazolla, "dirimir um erro é salvar a comunidade e nunca somente a si mesmo" (GAZOLLA, 2001, p.28).

O processo de purgação catártica acontece em vários momentos da tragédia Antígona, e nos deteremos, em particular, no desfecho da tragédia. O processo purificatório tem seu aspecto sagrado por conta da origem dionisíaca (embora no seu auge não se reconheça mais Dioniso) e das apresentações ritualísticas, mas

1 Pólis significa a cidade-estado. Na Grécia Antiga, era uma organização social constituída por cidadãos livres que discutiam e elaboravam as leis relativas à cidade. Dentro dos limites de uma pólis, ficavam a Ágora e a Acrópole. 
também apresenta um conteúdo educativo e cívico. É uma arte da polis e para a polis. A catarse "presenteia o assistente com a possibilidade de expandir seus julgamentos, sua capacidade de pensar sobre sua pessoa e suas relações com as outras pessoas (...) nos traz experiências emocionais de tal vigor, que provocam a purificação por sua vivência" (GAZOLLA, 2001, p.39).

Os personagens agem e, então, por uma espécie de revivescência, a audiência se purifica por retomar esses sentimentos. A ideia de que a tragédia está intrinsecamente ligada à política é, portanto, recorrente. A obra Antígona é filha de sua própria época e questiona o status político. A assistência vivencia as ações dos personagens e os diálogos da obra por meio de vivências cotidianas e políticas bem próximas aos próprios espectadores.

Percebemos, notoriamente, essa catarse ao longo de várias passagens do texto, mas, em particular, no desfecho da tragédia que iremos descrever em nosso artigo posteriormente. Na próxima seção, faremos uma breve descrição dos elementos da tragédia.

\section{Breve descrição da obra}

A obra relata o drama vivido por Antígona, filha de Édipo e Jocasta, depois que seu pai, já velho, cansado e cego, sai de Tebas para Colono. Em Tebas, ficam seus irmãos, Polinice e Etéocles (herdeiros do trono). Estes disputam o poder, mas findam por matar um ao outro. Creonte, rei de Tebas, como sucessor de Édipo e irmão de Jocasta, de acordo com as leis da polis, proíbe o sepultamento de Polinice, príncipe tebano considerado inimigo da cidade por comandar o exército de Argos na invasão de Tebas para exigir de seu irmão Etéocles o cumprimento do pacto de permutação no trono. $\mathrm{O}$ rei, portanto, priva-o de todo acesso ao reino dos mortos, $\mathrm{o}$ que é inconcebível para Antígona.

Sepultar o irmão se torna, para Antígona, um dever determinado por uma Lei que se encontra acima e além daquelas da cidade: a dos Deuses. A personagem, portanto, já havia transposto o limite da lei da polis ao decidir sepultar Polinice. E ela o sabe bem, pois conceder-lhe honras fúnebres é o mesmo que atribuir-lhe outro status: "Foi como irmão que ele morreu, não como escravo" (SÓFOCLES, 2004, p. 222). E era qualquer forma de reconhecimento que Creonte evitava com seu decreto.

Mediante a recusa de Antígona em acatar as leis da polis, Creonte faz novo decreto: que ela seja emparedada viva. E apesar dos apelos recebidos, ele permanece irredutível. Entretanto, quando o adivinho Tirésias o alerta sobre possíveis acontecimentos que viriam a desgraçar sua família e a cidade, ele retrocede. Porém, é tarde porque, ao dirigir-se ao túmulo, encontra Antígona morta e Hémon, seu filho e noivo de Antígona, mata-se sobre o corpo dela (SÓFOCLES, 2004, p. 253).

A rainha Eurídice, ao saber do suicídio do seu filho, também se mata. "[...] Creonte ao chegar no palácio com o cadáver do filho nos braços é avisado, pelo segundo mensageiro, que a soberana também já está morta" (SÓFOCLES, 2004, p. 256-257). 
Silva, E. E.;

PERrusi, M. S.;

Moraes, A. H.

Análise retórica

e moral de Antígona

\section{Antígona: discussão ética e política}

Creonte, sob um ponto de vista, está correto. Polinice recorreu ao exército de Argos para invadir a cidade de Tebas e tomar o poder, ainda que lhe fosse de direito por conta do acordo com o irmão. Fazendo isso, tornou-se inimigo de Tebas. Então, segundo a lei da cidade, um inimigo não teria honras fúnebres. Portanto, Creonte está correto e segue rigorosamente a legislação.

Antígona, por sua vez, também está correta ao defender a lei natural de enterrar os mortos da família, isto é, de defender as honras fúnebres do irmão. Portanto, o que temos é uma situação em que há correção de ambos os lados. No entanto, as coisas não são tão simples assim.

Observem a posição de Creonte que segue estritamente a lei. Ora, política não é apenas o cumprimento da lei, mas envolve muitas outras variáveis que também são políticas. Ou seja, a lei contempla o povo? Ouvir o povo é política. Antígona faz parte do povo e o coro já anuncia essa situação. Há uma tensão bem forte entre o enterro de Polinice, a discordância veemente de Creonte frente ao ato e a defesa vigorosa do cumprimento da lei da cidade. Nesse momento, temos a pausa dramática do coro que, após a ação, faz uma reflexão. Trata-se do estásimo bem conhecido que vai dos versos 332 a 377 (SÓFOCLES, 1992).

O estásimo começa com "Muitos prodígios há; porém nenhum maior do que o homem” (SÓFOCLES, 1992, verso 332). A palavra usada na tradução do texto foi "prodígios", mas Castoriadis discute os sentidos da palavra na versão original, "deinos". Segundo ele, "deinos" comportaria um duplo sentido, "maravilhoso" e "terrível", e Sófocles a teria usado com os dois sentidos. Assim, o ser humano seria ao mesmo tempo maravilhoso e terrível.

O ser humano, Sófocles nos descreve, distingue-se na sua condição natural por ultrapassar seus limites: através da técnica, do trabalho, ele ultrapassou os mares, lavrou a terra, etc. São ações próprias da cultura. A origem dessas ações é a própria humanidade. O homem teria ensinado a si mesmo e sozinho aprendeu, nenhum Deus lhe concedeu (como teria acontecido com Prometeu Acorrentado de Ésquilo) "a fala, o alado pensamento e as normas que regulam a cidade" (SÓFOCLES, 1992, verso 355). Só há uma única coisa que o ser humano não conseguiu ultrapassar: a sua condição mortal.

Consideramos que a parte final do estásimo seja uma chave para nossa interpretação de Antígona (SÓFOCLES, 1992, vv.365 a 377). Tudo que o coro descreveu sobre o homem, tudo que ele aprende de si mesmo (a linguagem, o pensamento, as normas da cidade) pode levar ora ao bem, ora ao mal. Isto é, como aponta Castoriadis (2000), é maravilhoso e terrível.

Aquele que soubesse levar em consideração os dois lados da questão, as leis da cidade e as leis dos deuses, conseguiria tornar a cidade venturosa. A tragédia acontece precisamente porque há, nos protagonistas, uma rigidez cega na defesa de uma das leis. Ambos são apaixonados por seu tema. Antígona, apaixonada por seu

Revista Letras, Curitiba, UFPR, n. 97, pp. 38-54, 
irmão, defende a lei familiar a todo custo. Creonte, apaixonado pelo poder e pela cidade, defende a lei da cidade a todo custo ${ }^{2}$.

Só há honras fúnebres porque há cidade: são suas leis que lhe garantem as honras fúnebres. E só há leis da cidade porque há cidadãos. É preciso, portanto, olhar os dois lados da questão. É precisamente essa arrogância (hybris), descrita também no estásimo quando fala de quem incorre no erro por audácia (CASTORIADIS, 2000), que vai fazer com que seja desencadeada toda a catástrofe na tragédia. O coro já anunciou que quem, por excesso, fixar-se em apenas um dos lados da questão pode desencadear a tragédia.

Em seguida, o diálogo entre Hémon e Creonte vai tratar de mostrar essa inflexibilidade do ponto de vista passional, isto é, um diálogo entre o inflexível Creonte e o conciliador Hémon, que é uma passagem de bela defesa da democracia. É precisamente quando aprendemos, pela democracia, que precisamos ouvir o outro lado.

Hémon, noivo de Antígona, ouve a população que é favorável à ação de Antígona: "Mas a mim é-me dado escutar na sombra como a cidade lamenta essa moça, porque, depois de ter praticado ações tão gloriosas, vai perceber de tal maneira, ela, que, de todas as mulheres, era a que menos o merecia" (vv.693 a 695).

No diálogo com o pai, Hémon lhe dá razão: "Nem eu poderia nem saberia afirmar que não tens razão ao falar assim" (vv. 685-686). Isso mostra sua clareza. No entanto, Creonte recusa-se a ouvi-lo: primeiro, por ele ser mais jovem; segundo, porque se mostra inflexível na defesa da lei da cidade. O coro, então, pontua que ambos têm razão: "Senhor, se ele dissertou com prosperidade, é natural que tu aprendas com ele, e tu, Hémon, com teu pai, por tua vez: pois ambas as partes disseram palavras sensatas" (vv.724-726). Ambos têm razão: aquele que diz que a lei deve ser cumprida e aquele que diz que o povo deve ser ouvido.

Creonte, contudo, recusa-se a ouvir os argumentos de Hémon, questionando quem deve conduzir a cidade numa postura claramente antidemocrática: "E a cidade é que vai prescrever-me o que devo ordenar?" (verso 734). Há uma disputa de autoridade. Hémon pontua o problema, mas, além de jovem, não exerce o poder.

Hémon diz a Creonte: "Mandarias muito bem sozinho numa terra que fosse deserta" (v. 739). Após reconhecer certa razão na defesa da lei, Hémon aponta que Creonte se considera o único a ter razão e, aqui, temos um problema chave na tragédia. Creonte não está disposto a ouvir, e, em grego, ele seria visto como um monos phronein, o único a ter razão. Essa inflexibilidade vai levar à catástrofe 3 . Diz, ainda, Hémon sobre essa questão: "Porque quem julga que é o único que pensa bem, ou que tem uma língua ou um espírito como mais ninguém, esse, quando posto a nu, vê-se que é oco" (vv. 708-710).

2 "Diz o poeta aos cidadãos de Atenas: mesmo quando temos razão, pode ser que a não tenhamos, pois nunca há uma última palavra no plano lógico. Efectivamente, os argumentos de Creonte e de Antígona, considerados enquanto tais, são impermeáveis um ao outro e não têm refutação lógica possível" (CASTORIADIS, 2000, p.26).

3 "A catástrofe se produz porque tanto Creonte como Antígona se aferram a suas razões, e não escutam as razões do outro" (CASTORIADIS, 1987, p.309). 
SIlva, E. E.;

PERrusi, M. S.;

Moraes, A. H.

Análise retórica e moral de Antígona

Sófocles levantou, nessa tragédia, questões fundamentais para o espírito humano, principalmente a do limite da autoridade do Estado sobre a consciência individual, e a do conflito entre as leis da consciência — não escritas - e o direito positivo. A sua Antígona é o primeiro grito de protesto contra a onipotência dos governantes e a prepotência dos mais velhos.

Nessa tragédia, Creonte encarna o dever de obediência às leis do Estado, e a heroína simboliza o dever de dar ouvidos à própria consciência. A nosso ver, Antígona é um dos maiores exemplos em que o tema central de um drama grego é um problema prático de conduta, envolvendo aspectos morais e políticos que poderiam ser discutidos com fundamentos e interesse idênticos em qualquer época e país.

O tradutor R. C. Jebb, na introdução à sua edição comentada da Antígona, sintetiza o problema da seguinte maneira:

Mas a questão não é um simples conflito entre a lei do Estado e os deveres religiosos; é um conflito entre a lei do Estado imposta com excessivo rigor, e uma afeição natural colocada acima das leis. Creonte está certo na letra e errado no espírito; Antígona está certa no espírito e errada na letra (JEBB apud KURY in SÓFOCLES, 2004).

Isso significa dizer que, da mesma forma que Creonte ultrapassou o limite devido quando, em seu edito, infringiu a lei divina, Antígona também o ultrapassou ao desafiar o edito. O drama seria, então, o conflito entre duas pessoas, que defendem seus próprios princípios de maneira intransigente.

Aristóteles, por exemplo, menciona a peça nas seguintes passagens de sua obra Retórica:

[...] Há na natureza um princípio comum do que é justo e injusto, que todos de algum modo adivinham mesmo que não haja entre si comunicação ou acordo; como, por exemplo, o mostra a Antígona de Sófocles ao dizer que, embora seja proibido, é justo enterrar Polinice, porque esse é um direito natural (ARISTÓTELES, I, 13, p.92-93, 2004):

Pois não é de hoje nem ontem, mas desde sempre que esta lei existe, e ninguém sabe desde quando apareceu (vv. 456-457).

É isso que a Antígona de Sófocles claramente quer exprimir quando diz que o funeral de Polinice era um ato justo apesar da proibição: ela pretende dizer que era justo por natureza. Segundo Pereira (2015), foi na obra Retórica que Aristóteles falou, pela primeira vez, sobre o direito natural, ou jusnaturalismo.

Em outro trecho da mesma obra, Aristóteles, ao falar das leis escritas e não-escritas, refere-se a Antígona, ao afirmar

Revista Letras, Curitiba, UFPR, n. 97, pp. 38-54, 
[....] a equidade é permanentemente válida e nunca muda, como a lei comum (por ser conforme à natureza), ao passo que as leis escritas estão frequentemente a mudar; donde as palavras pronunciadas na Antígona de Sófocles; pois esta defende-se, dizendo que sepultou o irmão contra a lei de Creonte, mas não contra a lei não escrita (ARISTÓTELES, Livro I, 15, p.97-98, 1375b, 2005):

Pois esta lei não é de hoje nem de ontem, mas é eterna [...] Esta não devia eu [infringir], por homem algum... (vv. 456, 458.)

Devemos enfatizar que os princípios da equidade são permanentes e imutáveis, e que a lei universal, tampouco, muda, pois se trata da lei natural, ao passo que as leis escritas, muitas vezes, mudam.

Assim, vimos que dramaturgos, como Sófocles, e filósofos, como Aristóteles e Castoriadis, não centralizam a relação indivíduo-sociedade (cidadão-polis) porque concebem os seres humanos como membros integrantes de uma comunidade (oikos-polis), e não como sujeitos singularizados fora de um contexto social. A ação moral, por isso mesmo, torna-se indissociável da ação política.

Segundo Freitag (1992), "a moralidade praticamente confunde-se com a ética, e esta com a decisão política, levando em consideração o outro, no interior de seu grupo ou de sua comunidade política".

Mais do que isso, a dimensão política da tragédia, em Castoriadis (1987), é ontológica e faz parte de uma visão de mundo. Não temos noção da consequência dos nossos atos. Mais do que ordem, no mundo humano, temos desordem. O resultado de ações inflexíveis, segundo Castoriadis, apareceria sob a forma de catástrofe. A respeito disso, o filósofo afirma:

A dimensão política da tragédia decorre antes de mais nada e
acima de tudo de sua base ontológica. O que a tragédia traz à
vista de todos - não 'discursivamente’ mas por apresentação - é
que o Ser é Caos. O Caos apresenta-se aqui, primeiramente, como
ausência de ordem para o homem, a falta de correspondência
positiva entre as intenções e as ações humanas, por um lado, e seus
resultados e consequências, por outro. Mais que isso, a tragédia
mostra não apenas que não somos senhores das consequências
de nossos atos, mas também que não dominamos nem mesmo a
sua significação (CASTORIADIS, 1987, p.307).

Ou seja, Creonte e Antígona reivindicam que suas ações são corretas, mas o resultado da ação inflexível deles é imprevisível no sentido de ser catastrófico. Não temos como saber as consequências de nossas decisões e, se essa decisão é autoritária e inflexível, ela não pode ser revista. Não conseguimos dar conta, nem racional, nem patologicamente. Não dominamos sequer a significação de nossos 
SIlva, E. E.; PERrusi, M. S.; Moraes, A. H. Análise retórica e moral de Antígona atos, ou seja, julgamos a correção da nossa ação, mas não percebemos os resultados da intransigência.

Na próxima seção, analisaremos aspectos da Antígona, de Sofócles, a partir dos elementos da arte retórica de Aristóteles, em particular dos gêneros do discurso.

\section{Análise de Antígona a partir da Retórica aristotélica}

Aristóteles, ao tratar da retórica enquanto arte, apresenta-nos algumas técnicas que têm por objetivo: (i) identificar os gêneros do discurso - a saber, deliberativo, judiciário e epidítico - a depender do tipo de orador, do assunto de que se fala, e do ouvinte; (ii) problematizar o caráter do orador tendo em vista que, para persuadir, esse caráter (éthos) deve ser "construído" como "verdadeiro" (mesmo que não o seja); (iii) apresentar análise dos meios de provas retóricas: éthos, pathos e logos; (iv) propor tipos de argumentos estabelecendo uma relação entre lógica e dialética.

Para o filósofo, a importância dessa arte consiste na capacidade de persuadir o ouvinte através do discurso oral, fazendo com que ele formule um juízo sobre a situação que a ele se apresenta. Nesse sentido, a retórica se liga, portanto, à política, aos costumes e à ética (JESUS, 2015).

\subsection{Gêneros do discurso}

Na obra Retórica, de Aristóteles, sabe-se que há três gêneros do discurso que, segundo o autor, podem ser vistos de acordo com o auditório. A respeito disso, ele afirma:

As espécies de retórica são três em número; pois outras tantas são as classes de ouvintes dos discursos. [...] De sorte que é necessário que existam três gêneros de discursos retóricos: o deliberativo, $\mathrm{o}$ judicial e o epidítico (ARISTÓTELES, 1998, Livro I, cap. 3, p.104).

No texto de Antígona, podemos encontrar os três gêneros. O deliberativo (ou político) trata da administração geral do Estado e pode ser visto no início da obra quando Creonte apresenta, aos representantes da cidade (Coro), como ele irá governar Tebas, uma vez que os filhos de Édipo estão mortos. Temos isso no diálogo entre Creonte e o Coro nos versos 163-175; 195-205 e 211-219.

O gênero do discurso judiciário (forense) abrange todos os discursos pronunciados nos tribunais ou nas assembleias, na presença de juízes, com o fim único de se fazer justiça (REBOUL, 2004). Detectamos o uso dele, sobretudo, na cena em que, após o flagrante do delito e a detenção de Antígona pelos guardas, Creonte a interroga, julga e condena. Esse tipo de discurso pode ser percebido no diálogo entre Creonte e Antígona nos versos 442-449 e na sentença proferida por Creonte ao Coro nos versos 770-780.
Revista Letras, Curitiba, UfPR, n. 97, pp. 38-54, jan./jun. 2018. ISSN 2236-0999 (versão eletrônica) 
O gênero epidíctico (ou demonstrativo) se refere ao elogio ou à censura, ao belo e ao feio. Visa mostrar a virtude ou defeito de uma pessoa, ou alguma coisa, por meio do elogio ou censura (ARISTÓTELES, 1998; REBOUL, 2000).

Identificamos o gênero epidíctico em vários trechos, mas, em particular, nos elogios do Coro ao rei Creonte, como mostram os versos 211-220; nos elogios do adivinho Tirésias a Creonte nos versos 990 - 999; nas censuras feitas por Antígona a Creonte nos versos 519 - 523, e nas censuras de Hémon ao rei nos versos 740 - 755 .

\subsection{Análise do éthos, pathos e logos na Antígona de Sófocles}

Aristóteles define três tipos de argumentos no sentido de instrumentos de persuasão: tem-se o ethos e o pathos, que são de ordem afetiva, e o logos, que é racional (REBOUL, 2000).

Éthos - esse tipo de argumento é o caráter moral que o orador deve assumir para gerar confiança no auditório, mostrando-se sensato (capaz de dar conselhos razoáveis e pertinentes), simpático (capaz de ajudar o auditório) e sincero (não dissimulando o que pensa nem o que sabe), como diz Aristóteles na obra Retórica (2005, Livro II, 1377a, em diante).

Na tragédia, temos o éthos quando Antígona defende a sua ideia em relação ao sepultamento de seu irmão Polinice frente ao edito promulgado pela lei. Essa ideia está no trecho em que Ismênia diz para Antígona que vai obedecer à lei de Creonte e Antígona responde à irmã dizendo:

Procede como te aprouver; de qualquer modo hei de enterrá-lo e será belo para mim morrer cumprindo esse dever: repousarei ao lado dele, amada por quem tanto amei e santo é o meu delito, pois terei de amar aos mortos muito, muito tempo mais que aos vivos (SÓFOCLES, 2004, versos 69-78).

Segundo Jesus (2015), o éthos de Creonte revela que ele é o arquétipo do herói que aprende tardiamente, pois, como o deus Cronos, "devora" seu filho e sua futura nora (que seria também sua "filha"). E o éthos de Hémon o aponta como aquele que sabiamente pode intervir enquanto conselheiro do pai, já que toda a sua intervenção buscava expandir o período político de Creonte a outro patamar, conforme percebemos nos excertos a seguir:

Hemon [...] - nenhuma, em tempo algum, "terá por feitos tão gloriosos quanto os dela [Antígona] "sofrido morte mais ignóbil; ela que, "quando em sangrento embate seu irmão morreu "não o deixou sem sepultura, para pasto "de carniceiros cães ou aves de rapina, "não merece, ao contrário, um áureo galardão?" (SÓFOCLES, 2004, versos 692-700). 
Silva, E. E.;

Perrusi, M. S.;

Moraes, A. H.

Análise retórica

e moral de Antígona
[...] - não há vergonha alguma, mesmo sendo sábio, em aprender cada vez mais, sem presunções (SÓFOCLES, 2004, versos 710 -712).

O éthos de Hémon tem, ainda, o intuito de revelar ao sujeito interpretante que o bem político não é uma verdade pronta, mas um processo em curso, um caminho nunca acabado. Seu éthos, tal como o de Antígona, revela-se porta-voz dos novos tempos ou da necessidade de se abrir para esse fato incontestável.

Ismenia, irmã de Antígona, ao contrário dessa, opta por obedecer à lei e à vontade do rei Creonte, pois ela procura, mediante sua condição de oprimida, reavivar o fato de que as mulheres, sozinhas, não são capazes de modificar as leis.

[...] não nos esqueçamos de que somos mulheres e, por conseguinte, não poderemos enfrentar, só nós, os homens. Enfim, somos mandadas por mais poderosos e só nos resta obedecer a essas ordens e até a outra inda mais desoladora. Peço indulgência aos nossos mortos enterrados mas obedeço, constrangida, aos governantes; ter pretensões ao impossível é loucura (SÓFOCLES, 2004, versos 61-67).

Esse excerto nos faz perceber outra preocupação tratada por Sófocles em sua obra, a saber: a exclusão da mulher enquanto cidadã.

E, apesar da resignação de Ismenia, Antígona tenta dissuadi-la, conforme percebemos nos fragmentos abaixo:

Minha querida Ismenia, irmã do mesmo sangue, conheces um só mal entre os herdados de Édipo que Zeus não jogue sobre nós enquanto vivas? (SÓFOCLES, 2004, versos 1-5).

[...] Esse é o decreto imposto pelo bom Creonte a mim e a ti (melhor dizendo: a mim somente) [...] Ele não dá pouca importância ao caso: impõe aos transgressores a pena de apedrejamento até a morte perante o povo todo. Agora sabes disso e muito em breve irás tu mesma demonstrar se és bem-nascida ou filha indigna de pais nobres (SÓFOCLES, 2004, versos 31-38).

[...] Ele não pode impor que eu abandone os meus (SÓFOCLES, 2004, verso 49).

Entretanto, Antígona não consegue convencer sua irmã a mudar de ideia. Ismênia diz:

Mas, nessas circunstâncias, infeliz irmã, teria eu poderes para te ajudar a desfazer ou a fazer alguma coisa? (SÓFOCLES, 2004, verso 40).

[...] Agora que restamos eu e tu, sozinhas, pensa na morte inda pior que nos aguarda se contra a lei desacatarmos a vontade do rei e a sua força (SÓFOCLES, 2004, versos 57-60).
Revista Letras, Curitiba, UFPR, n. 97 , pp. 38-54, jan./jun. 2018. ISSN 2236-0999 (versão eletrônica) 
O éthos de Antígona se coloca em ruptura em relação aos limites e aos compromissos da vida cívica. Seu engajamento político se inscreve na fidelidade a uma justiça atemporal e divina.

A determinação de Antígona é inflexível, inabalável, surda, como vimos, até mesmo nas ordens dadas a sua irmã. Antígona parece flutuar entre fronteiras, entre a norma(lidade) e a prudência. Seu éthos reflete, portanto, uma personalidade exagerada/ultrajada, que a conduz além do medo e do conformismo.

Phatos - é o conjunto de emoções, paixões e sentimentos que o orador deve suscitar no auditório. Esse tipo de argumento, na maioria das vezes, envolve dor e prazer, uma vez que a maioria das pessoas só muda por uma grande dor ou por uma grande perspectiva de prazer. O pathos tem o objetivo de gerar no auditório as emoções, como ira e calma, amizade e inimizade, temor e confiança, vergonha e falta de vergonha, amabilidade e indelicadeza, piedade e indignação, inveja e disputa (ou competição).

Na obra de Sófocles, temos o phatos no trecho em que há a ameaça de Creonte ao guarda pela entrega de um culpado pela tentativa de sepultamento de Polinice:

Creonte, com ira, ameaça os guardas ao dizer:

\begin{abstract}
Sei muito bem que os guardas foram corrompidos e subornados para agir assim por eles. Nunca entre os homens floresceu uma invenção pior que o ouro; até cidades ele arrasa, afasta os homens de seus lares, arrebata e impele almas honestas às ações mais torpes e incita ainda os homens ao aviltamento, à impiedade em tudo. Mas, quem age assim por interesse, um dia paga o justo preço. Se a Zeus ainda agrada a minha reverência, escuta e dize aos outros guardas: juro agora que se não descobrirdes o real autor desse sepultamento e não o conduzirdes à frente de meus olhos, simplesmente a morte não há de ser pena bastante para vós; sereis dependurados todos, inda vivos, até que alguém confesse o crime! Sabereis de quem é vantajoso receber dinheiro de hoje em diante e aprendereis ao mesmo tempo que não é bom querer ganhar de qualquer modo; vereis que o lucro desonesto leva os homens com mais frequência à ruína que à prosperidade! (SÓFOCLES, 2004, versos 294-314).
\end{abstract}

Logos - diz respeito à argumentação propriamente dita do discurso. É o aspecto dialético da retórica. Aristóteles distingue o argumento do tipo entimema daquele do tipo exemplo. Este segundo pode ser: (i) real (baseado em fatos históricos); ou (ii) fictício (baseado em fatos inventados, ex. fábulas e parábolas).

No texto de Antígona, escolhemos identificar o exemplo porque eles são persuasivos em todas as circunstâncias. No trecho abaixo, temos o logos, na forma de exemplo, baseado em fatos históricos:

Falaram-me de uma estrangeira, há muito, filha de Tântalo, da terra forígia, e de seu triste fim no alto do Sípilo, aprisionada por 
Silva, E. E.;

Perrusi, M. S.;

Moraes, A. H.

Análise retórica e moral de Antígona muitos rochedos que em volta dela, como hera tenaz cresciam sempre; e ainda hoje contam que a chuva não cessava de molhar-lhe o corpo agonizante, nem a neve, enquanto as lágrimas que lhe desciam dos olhos orvalhavam o seu colo. Prepara-me o destino enterro igual (SÓFOCLES, 2004, versos 824-834).

Como vimos, Aristóteles (2005) vê a retórica como a prática que proporciona ao orador oportunidades sociais de aprendizagem quanto a lida com o público durante um discurso, projetando-se enquanto um orador digno de fé. $\mathrm{Na}$ arte retórica, até mesmo a posição social do orador é levada em consideração enquanto elemento que valida ou dá credibilidade a ele.

Portanto, podemos dizer que a tragédia de Antígona é marcada por dois tipos de sofrimento: aquele que advém de um excesso de paixão (pathos) e aquele que se origina do éthos (caráter moral). Sófocles ocupou-se nessa tragédia dos seguintes elementos: i) leis gregas de seu tempo, a fim de ordenar o mundo e os atos para que as coisas sejam justas; e ii) destino humano e destino do herói que sofre e é destruído.

A obra de Sófocles nos demonstra, mediante os argumentos dos tipos éthos, pathos e logos - apresentados por Antígona, pelo Coro e por Tirésias -, que os governantes devem buscar ajustamentos progressivos que visem ao bem comum, pois essas adequações objetivam o equilíbrio, a temperança e a prudência nas ações.

Assim, se o perdão que Antígona pedia para Polinice e a revisão da sentença sugerida por Hémon fossem considerados, o governo de Creonte poderia ter sido o de uma cidade pacificada. Contudo, parece-nos que a temperança e a pacificação não pertencem ao universo trágico de Antígona.

\section{Considerações finais}

A partir do exposto neste trabalho, vimos que, na antiguidade, os sofistas e os filósofos desenvolveram uma habilidade prodigiosa de articular um discurso sobre política, moral, metafísica ou qualquer outro tema que merecesse a defesa, ou a acusação, o elogio ou a censura. Nesse período, a eloquência na oratória dos discursos causava fascínio e deslumbramento na população.

Atualmente, os discursos retóricos causam interesse e curiosidade nas pessoas que têm a necessidade de empregar a arte de convencer e persuadir. Nesse trabalho, pesquisar as discussões de Castoriadis e aplicar a retórica aristotélica a uma das tragédias de Sófocles foi uma honra e um privilégio, uma vez que consideramos o pensamento filosófico e a arte retórica indispensáveis e úteis na vida social, política e profissional de todo cidadão, pois, para nós, ambos são instrumentos de reflexão e linguagem mais completos para análise, interpretação e prática do discurso.

Mas, ao analisarmos os temas da justiça e da democracia em Antígona, percebemos que a retórica empregada por Sófocles, na construção da tragédia, renascia sempre que as ideologias se desmoronavam. Assim foi o caso de Antígona,

Revista Letras, Curitiba, UFPR, n. 97, pp. 38-54, 
ao perceber a possibilidade de sua irmã Ismênia ser condenada à morte por causa das suas crenças, e o de Creonte, ao reconsiderar a sua decisão após ser avisado por Tirésias das fatalidades que ainda poderiam ocorrer na sua família.

Em ambos os casos, os protagonistas utilizam a retórica como arte da persuasão e do convencimento, a saber: Creonte, ao apelar para a misericórdia dos deuses para que não ocorresse mais nenhuma desgraça na sua família, e Antígona, ao argumentar com Creonte pela não condenação de Ismênia.

Por fim, o que observamos é que, em Antígona, há argumentos persuasivos que não dialogam. Precisamos, portanto, pontuar onde está o aprendizado na tragédia, e, para isso, falamos sobre quem sobrevive e porque sobrevive. Ismênia passa de uma mulher medrosa que reconhece a importância da lei natural, mas não se sente capaz de mudar a lei da polis, para uma mulher assertiva que aprende com as atitudes de Antígona.

A inflexibilidade de Creonte condena Antígona à morte. No entanto, ele volta atrás tarde demais, pois Antígona já havia se antecipado e se matado. A morte de Antígona é seguida da morte de seu noivo, Hémon, e Eurídice, mãe de Hémon.

Creonte lamenta a morte do filho e deseja sua própria morte. O Coro, contudo, adverte que tal decisão só cabe ao futuro (vv. 1330-1335). Antígona, além da intransigência no cumprimento da lei divina, comete o descomedimento de tirar sua própria vida. Creonte, então, implora a morte e reconhece que foi sua intransigência que levou às mortes de Hémon e Eurídice: "levai para longe este homem tresloucado, que sem querer te matou, filho” (vv. 1339-1341).

Mas o coro, como já havíamos indicado anteriormente em outras passagens, profere as palavras finais da tragédia, conclamando ao bom senso: "Para ser feliz, bom senso é mais que tudo. Com os deuses não seja ímpio ninguém. Dos insolentes palavras infladas pagam a pena grandes castigos; a ser sensatos os anos lhe ensinaram" (vv. 1349-1353).

Em Antígona, pois, busca-se o bom senso, ninguém deve ser sábio sozinho. Foi preciso a catástrofe para que Creonte aprendesse o que os anos lhe ensinaram: a ter bom senso. E, assim, concluímos com a purificação das emoções em seu caráter educativo e cívico. 
Silva, E. E.;

Perrusi, M. S.;

Moraes, A. H.

Análise retórica e moral de Antígona

ARISTÓTELES. Retórica. Introdução: Manuel Alexandre JÚNIOR. Tradução do grego e notas: Manuel Alexandre Júnior, Paulo Farmhouse Alberto e Abel do Nascimento Pena. Lisboa: WWF: Martins Fontes, 2005.

. Retórica. Introdução: Manuel Alexandre JÚNIOR. Tradução do grego e notas: Manuel Alexandre Júnior, Paulo Farmhouse Alberto e Abel do Nascimento Pena. Lisboa: Casa da Moeda, 1998.

Poética. Coleção Os Pensadores, vol.IV. São Paulo: Abril Cultural, 1973

CASTORIADIS, C. As Encruzilhadas do Labirinto 2: os domínios do homem. Rio de Janeiro: Paz e Terra, 1987.

Figuras do Pensável: as encruzilhadas do labirinto. Lisboa: Instituto

Piaget, 2000.

FREITAG, B. Itinerários de Antígona - A questão da moralidade. São Paulo: Papirus, 1992.

GAZOLLA, Rachel. Para não ler ingenuamente uma tragédia grega. São Paulo: Loyola, 2001.

JAEGER, W. Paidéia: a formação do homem grego. Trad. Artur M. Parreira. São Paulo: Martins Fontes, 2001.

JESUS, S. M. O éthos em Antígona, de Sófocles. Revista Eletrônica de Estudos Integrados em Discurso e Argumentação, Ilhéus, n. 9, p. 137-152, dez.2015.

PEREIRA, A.L.G. Confluências entre mito, literatura e direito em Édipo Rei, de Sófocles. Dissertação em Letras. Unesp: São José do Rio Preto, 2015.

LESKY, Albin. A Tragédia Grega. São Paulo: Perspectiva, 2006

LORAUX, Nicole. Maneiras Trágicas de matar uma mulher: imaginário da Grécia Antiga. Rio de Janeiro: Zahar, 1995.

MARCONDES, D. Iniciação à História da Filosofia. Rio de Janeiro: Jorge Zahar, 1998.

MEYER, M. Questões de retórica: linguagem, razão e sedução. Trad. Antonio Hall. Lisboa: Edições 70, 2007.

NIETZSCHE, Friedrich. Introdução à Tragédia de Sófocles. Rio de Janeiro: Zahar, 2006.

REBOUL, O. Introdução à Retórica. Tradução: Ivone Castilho Benedetti. São Paulo: Martins Fontes, 2000.
Revista Letras, Curitiba, UFPR, n. 97, pp. 38-54, jan./jun. 2018. ISSN 2236-0999 (versão eletrônica) 
Introdução à retórica. Trad. Ivone Castilho Benedetti. São Paulo:

Martins Fontes, 2004.

SÓFOCLES. A Trilogia Tebana. Tradução: Mário da Gama Kury. Rio de Janeiro: Zahar, 1989.

A trilogia tebana: Édipo rei, Édipo em Colono, Antígona. Trad. de Mário da Gama Kury. 15 ed. Rio de Janeiro: Jorge Zahar Ed., 2004.

Calouste, 1992.

Antígona. Trad. de Maria Helena da Rocha Pereira. 6 ed. Coimbra:

Submetido em: 27/11/2017

Aceito em: 29/04/2018 